\title{
EVALUATION OF ANTIPROLIFERATIVE POTENTIAL OF MYRMECODIA PENDANS AND ITS ACTIVITY ON IL-8 SECRETION IN COLON CANCER CELL
}

\author{
AURICA ELISABETA MOATAR ${ }^{1}$, CRISTIAN SEBASTIAN VLAD ${ }^{1 *}$, DALIBORCA CRISTINA \\ VLAD $^{1}$, DOINA MIOARA VERDES ${ }^{2}$, MARIOARA NICOLETA FILIMON $^{3}$, OCTAVIAN BLOJU $^{3}$, \\ FLORIN BORCAN $^{4}$, CRISTINA ADRIANA DEHELEAN ${ }^{4}$, VICTOR DUMITRASCU $^{1}$
}

\author{
${ }^{1}$ Department of Pharmacology and Biochemistry, Faculty of Medicine, "Victor Babeș” University of Medicine and \\ Pharmacy, 2 Eftimie Murgu Square, 300041, Timisoara, Romania \\ ${ }^{2}$ Department of Morphologic Microscopy, Faculty of Medicine, "Victor Babeș” University of Medicine and Pharmacy, 2 \\ Eftimie Murgu Square, 300041, Timişsoara, Romania \\ ${ }^{3}$ Department of Biology and Chemistry, Faculty of Chemistry, Biology and Geography, West University Timișoara, 16 \\ Pestalozzi Street, 300315, Timișoara, Romania \\ ${ }^{4}$ Department of Toxicology, Faculty of Pharmacy, “Victor Babeș” University of Medicine and Pharmacy, 2 Eftimie Murgu \\ Square, 300041, Timişoara, Romania
}

*corresponding author: vlad.cristian@umft.ro

\begin{abstract}
Myrmecodya pendans ( $M$. pendans, Rubiaceae family) is a plant with multiple biological properties due to its active compounds. Although it is successfully used in the origin area, in various types of diseases (from infectious disease to diabetes or cancer), just a few studies have analysed its chemical content and its antitumour effects. The present study reports the antiproliferative biological activities of aqueous and ethanolic extracts of $M$. pendans in colon cancer cells (HCT116) associated with interleukin 8 (IL-8) secretion. Tumour cells were incubated with different concentrations of extract (between 150 and $600 \mu \mathrm{g} / \mathrm{mL}$ ) for 24, 48 and $72 \mathrm{~h}$. Cellular metabolic activity was measured using the 3-(4,5-dimethylthiazol-2-yl)2,5-diphenyltetrazolium bromide (MTT) colorimetric assay. The IL-8 secretion was analysed using the Elisa method. Both extracts exhibited moderate antitumour activity, dose and time dependent in cells incubated with the ethanolic extract 24 and $72 \mathrm{~h}$, with IC50 value of $566.087 \mu \mathrm{g} / \mathrm{mL}$ at 72 hours incubation. The exposure of the cells to aqueous extracts decreased the rate of cell multiplication, dependent on dose and incubation time. The IC50 was $587.95 \mu \mathrm{g} / \mathrm{mL}$, and $512 \mu \mathrm{g} / \mathrm{mL}$ respectively for a period of 48 and $72 \mathrm{~h}$ incubation. The extracts of $M$. pendans did not influence IL-8 levels in cell cultures.
\end{abstract}

\section{Rezumat}

Myrmecodya pendans (M. Pendans, Rubiaceae) este o plantă cu multiple proprietăți biologice datorită compușilor săi activi. Deși este utilizată cu succes în zona de origine, în diferite tipuri de boli (de la boli infecțioase la diabet sau cancer), doar puține studii au analizat conținutul său chimic și efectele sale antitumorale. Prezentul studiu raportează activitățile biologice antiproliferative ale extractelor apoase și etanolice ale $M$. pendans în celulele cancerului de colon (HCT116) asociate cu secreția de interleukină 8 (IL-8). Celulele tumorale au fost incubate cu concentrații diferite de extract (între 150 şi 600 $\mu \mathrm{g} / \mathrm{mL}$ ) pentru 24, 48 și 72 ore. Activitatea metabolică celulară a fost măsurată prin testul colorimetric MTT. Secreția IL-8 a fost analizată prin metoda Elisa. Ambele extracte au prezentat o activitate antitumorală moderată, dependentă de doză și timp în celulele incubate cu extract etanolic la 24 și 72 ore, cu o valoare IC50 de 566,087 $\mu \mathrm{g} / \mathrm{mL}$ la 72 ore de incubare. Expunerea celulelor la extracte apoase a scăzut viteza de înmulțire a celulelor, dependentă de doză și de timpul de incubare. IC50 a fost $587,95 \mu \mathrm{g} / \mathrm{mL}$, respectiv $512 \mu \mathrm{g} / \mathrm{mL}$ pentru o perioadă de incubare de 48 și 72 ore. Extractele de $M$. pendans nu au influențat nivelul IL-8 în culturile celulare.

Keywords: antiproliferative, ethanolic and aqueous extracts, HCT116 cells, IL-8, Myrmecodia pendans

\section{Introduction}

Phytotherapy is the oldest therapy used in the world; all ancient peoples had extensive knowledge of empirical phytotherapy, the plants being used as a source of food for people but also as a source of medicines and healing drinks. Beginning with a flavonoids mixture from the leaf of Acinos alpinus [1], allicin from garlic and tyramine from mistletoe [2], capsaicin from chili peppers [3], 6-, 8- and 10-gingerols from ginger [4], and different pentacyclic terpenoids from birch bark [5], all of these phytocompounds have been used for millennia.

Colon cancer incidence rate and mortality represent nowadays a serious public health issue in the world as it is increasing at variable rates in population. Treatment with chemotherapeutic agents may cause 
resistance in some cases. For this reason, research of innovative anti-cancer agents is required. Certain plants have the capacity to prevent and/or fight against cancer due to many virtues that they contain. Compounds with biological activities are characterized by high performance analytical techniques such as liquid and gas chromatography tandem mass spectrometry [6]. Myrmecodia pendans, also named the ant nest plant and sarang semut in local language, is a South-East Asian native plant that has been traditionally and safely used in Indonesia to treat diverse diseases. Since 1950s, people of Papua were preparing the plant as a porridge mixture or boiled drink for its ability to boost the immune system. $M$. pendans displays an important antitumour activity as an implicit anticancer agent [7]. Therefore, it can inhibit various types of human cancers including colon, liver, prostate, blood, breast, brain, cervical, lung and skin [8]. Furthermore, it is a remedy for associated systemic diseases, like infectious disease, tuberculosis, leukaemia, kidney, heart and prostate diseases, besides different allergies, haemorrhoid, rheumatism and migraine [9]. The active substances reveal the effectiveness of the plant; it consists of flavonoids, tannins, polyphenols that insure the antioxidant function, as well as glycosides [10]. These active compounds of polyphenols are antimicrobial and antidiabetic, in addition to their anticancer properties. M. pendans is potent for surmounting cancer cells. Several cells, along with cancer cells, produce IL-8 which is a chemokine family oncoprotein. In fact, IL-8 levels tend to increase in progressive cancer. Cytokine protein IL-8 has an important function in the inflammatory process [11]. Indeed, in tumours and metastases, IL- 8 promotes $\mathrm{T}$ cell infiltration, tumourigenesis, angiogenesis and chemoresistance [12].

In our study, the antiproliferative activity of $M$. pendans extracts in colon cancer cell was tested. We also analysed the effects of these $M$. pendans extracts on the secretion of IL-8 in the colon cells cancer.

\section{Materials and Methods}

MTT (3-(4,5-dimethylthiazol-2-yl)-2,5-diphenyltetrazolium bromide) assay (Vybrant Cell proliferation assay), cell culture media and reagent, phosphatebuffered saline (PBS) and dimethyl sulfoxide (DMSO) were purchase from Invitrogen. Ethanol (99.8\%) and distilled water were purchased from Sigma-Aldrich. HCT116 cell was kindly provided by Prof. Dumitrescu (The University of Agricultural Sciences and Veterinary Medicines of Timișoara, Romania). IL8 Human Elisa Kit was obtained from Boster Biological Technology (Pleasanton CA, USA, Catalogue ELISA Kit \#EK0413). This study uses raw materials of Myrmecodya pendans obtained from the Papua region. The extraction was carried out from dry plant material in ethanol and water (10 g plant material per $100 \mathrm{~mL}$ solvent). The solvents were evaporated and stock solutions were prepared in DMSO $1000 \mu \mathrm{g} / \mathrm{mL}$ for each solvent. From the stock solutions, the final test concentrations (150, 300,450 and $600 \mu \mathrm{g} / \mathrm{mL}$ ) were performed by dilution in culture media.

The cytotoxic potential evaluation of $M$. pendans extracts was performed using the colorimetric MTT assay. $2 \times 10^{4}$ cells $/ \mathrm{mL}\left(2 \times 10^{3}\right.$ cells/well) were seeded in $100 \mu \mathrm{L}$ media. HCT116 cells line were grown in Dulbecco's Modified Eagle Medium/Nutrient Mixture F-12 (DMEMF12) media (with or without test substances), at $37^{\circ} \mathrm{C}$ and $5 \% \mathrm{CO}_{2}$. HCT116 cells were exposed to various concentrations of ethanol and aqueous extracts of $M$. pendans $(150,300,450$ and $600 \mu \mathrm{g} / \mathrm{mL}$ ). After 24, 48 and 72 hours, $25 \mathrm{~mL}$ of MTT $(5 \mathrm{mg} / \mathrm{mL}$ PBS) were added in the wells. After 4 hours of incubation at $37^{\circ} \mathrm{C}$, the culture specific media was discarded and $100 \mathrm{~mL}$ of DMSO was added. Optical density at $540 \mathrm{~nm}$ was analysed (Tecan microplate reader). The test was performed in triplicate. IL-8 levels were analysed using our own standard curve (optical density $v s$. concentration) in the case of 8 standard concentrations $(0$ - 15.6 - 31.2 - 62.5 - 125 $250-500-1000 \mathrm{pg} / \mathrm{mL}$ ). Elisa method (test range $15.6-1000.0 \mathrm{pg} / \mathrm{mL}$ ) was performed to determine IL-8 level in the cell culture supernatant. The optical density was measured at $450 \mathrm{~nm}$.

\section{Results and Discussion}

Myrmecodia pendans originate from the eastern part of Indonesia. Some studies have emphasized that this plant may be useful in anticancer therapy. However, the extracts therapeutic effects and the active biological compounds activity of $M$. pendans are known in a lower manner. $M$. pendans extracts chemical analyses indicate that these plants contain flavonoid, tannin, as well as tocopherols, phenols and various minerals [10]. Also, some of the flavonoids mechanisms of action are known, such as the carcinogen inactivation, the antiproliferation, the cell cycle inhibition, the apoptosis induction, and the angiogenesis inhibition. A significant decrease in Burkitt lymphoma cell number was observed after the treatment with ethyl-acetate extract of $M$. pendans. There was a significant relationship between the concentrations of the extract, the period of incubation and the number of cells that can survive after being treated with the ethyl-acetate extract [13]. We attempted to evaluate the antiproliferative potential of the $M$. pendans ethanolic and aqueous extracts on HCT116 cancer cells. The MTT test results showed a moderate decrease in the cell multiplication rate. Thus, the cell proliferation inhibition was dose and time dependent for the ethanolic extracts at 24 and 72 hours incubation period. IC50 (minimum inhibitory concentration) was $566.087 \mu \mathrm{g} / \mathrm{mL}$ for $72 \mathrm{~h}$ incubation time (Figure 1). 


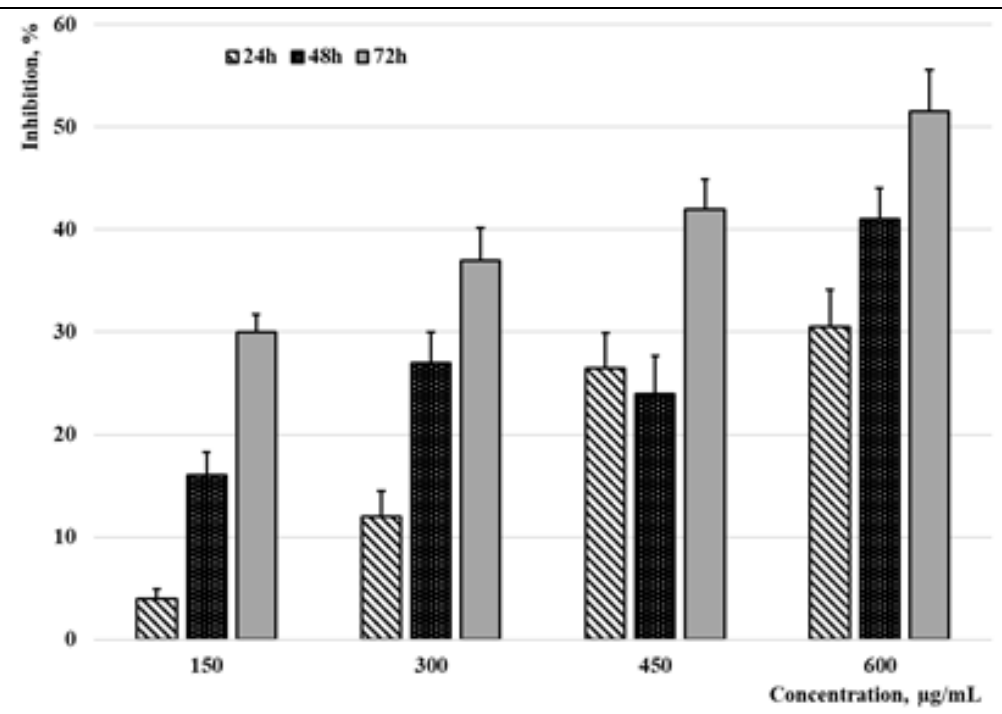

Figure 1.

Suppression of cell growth (MTT assay) - ethanolic extracts

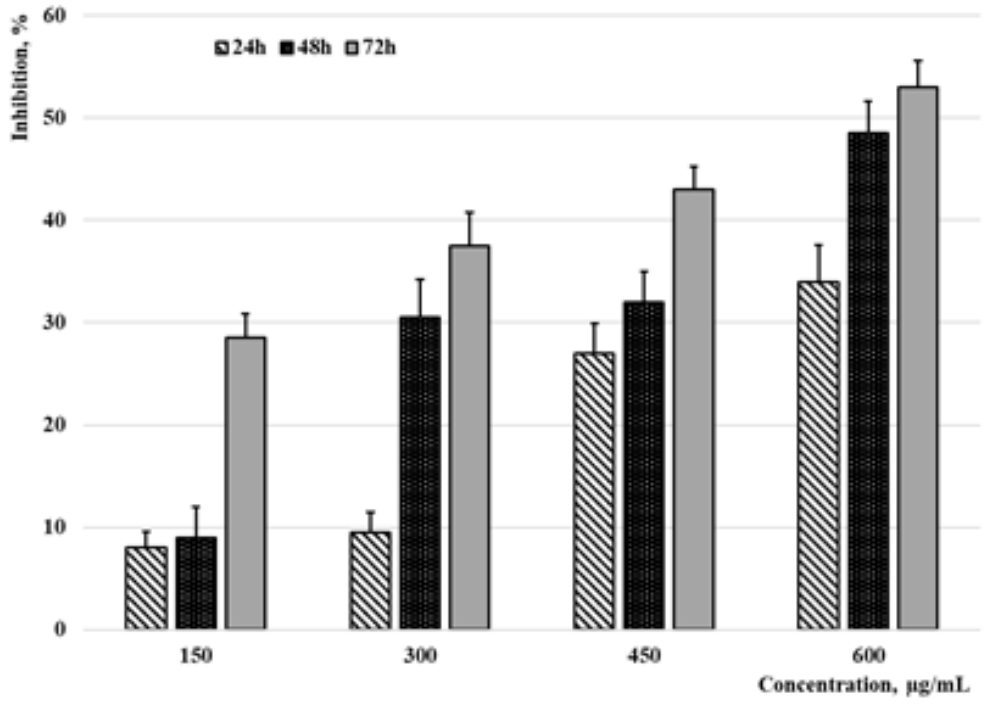

Figure 2.

Suppression of cell growth (MTT assay) - aqueous extracts

IC50 was not reached for the cells incubated with the ethanolic extracts at 24 and 48 hours. At 24, 48 and 72 hours incubation with aqueous extracts, the inhibition of HCT116 cell proliferation was dose and time-dependent (Figure 2); the IC50 was $587.95 \mu \mathrm{g} / \mathrm{mL}$, respectively $512 \mu \mathrm{g} / \mathrm{mL}$ at 48 and $72 \mathrm{~h}$ incubation.

Although there are just a few studies in the literature describing the antitumoural potential of $M$. pendans, some research groups have already reported promising results. Thus, Achmad et al. have shown that in squamous cell carcinoma of tongue, the flavonoids obtained by extraction with ethyl-acetate possess antitumour activity on molecular signalling pathways including Akt and NFkB (nuclear transcription factor) [13]. Their cytotoxicity test results reported different values for IC50 depending on the properties of the extraction solvent: ethyl-acetate, ethanol, hexane, and water, respectively 452.059, 938.003, 2691.535 and
$12302.690 \mu \mathrm{g} / \mathrm{mL}$. Another study reported a cell growth inhibition (Burkitt's lymphoma cancer cell) based on the concentration: the growth inhibition started from the lowest concentration of $15.625 \mathrm{pg} / \mathrm{mL}$. Also, the incubation time (24, 48 and 72 hours) evidenced a direct proportionality with the cell growth inhibition rate, namely, the longer the incubation period is, the higher cell growth inhibition is [14]. A study realized by Soeksmanto et al. regarding the effects of $M$. pendans extracts on HeLa and MCM-B2 cell lines, reported that polar extracts, obtained in water, had a higher anticancer activity compared to non-polar extracts (extracts obtained in ethyl-acetate and n-butanol) [15]. $\mathrm{N}$-hexane fraction of $M$. pendans extracts presented antitumour activity in colon cancer cells lines Caco2 and HCT116. However, the value of IC50 differs depending on the colon cancer type, being higher for the HCT116 cells compared to the one for Caco 2 cells 
FARMACIA, 2020, Vol. 68, 4

[16]. The decrease of cell proliferation, highlighted in the present study, can be explained by activating apoptosis pathways, fact suggested by some studies. In HSC-3 cells (human squamous carcinoma cells), M. pendans induces apoptosis by pro-apoptotic (Bax) and anti-apoptotic BCL-2 markers action [17]. $M$. pendans determines the apoptosis induction by both the extrinsic and intrinsic pathways, causing at the same time the induction of cyclin-dependent kinase p27Kip1 and cyclin E overexpression [18]. On normal fibroblasts cells, the alcoholic and aqueous extract of $M$. pendans has no cytotoxic effect [19], which suggests the biocompatibility with healthy cells.

Although, we have demonstrated the anti-proliferative effect of $M$. pendans aqueous and ethanolic extracts, the action on HCT116 cells did not caused significant changes in IL-8 synthesis. Despite the concentration or the incubation period with the extracts, IL-8 levels in the cell supernatant from the culture, were not significantly modified compared to the control (Figure 3 ). Interleukin 8 is a peptide in the cytokine family secreted by various cell types that exhibits a proinflammatory effect $[8,20]$.

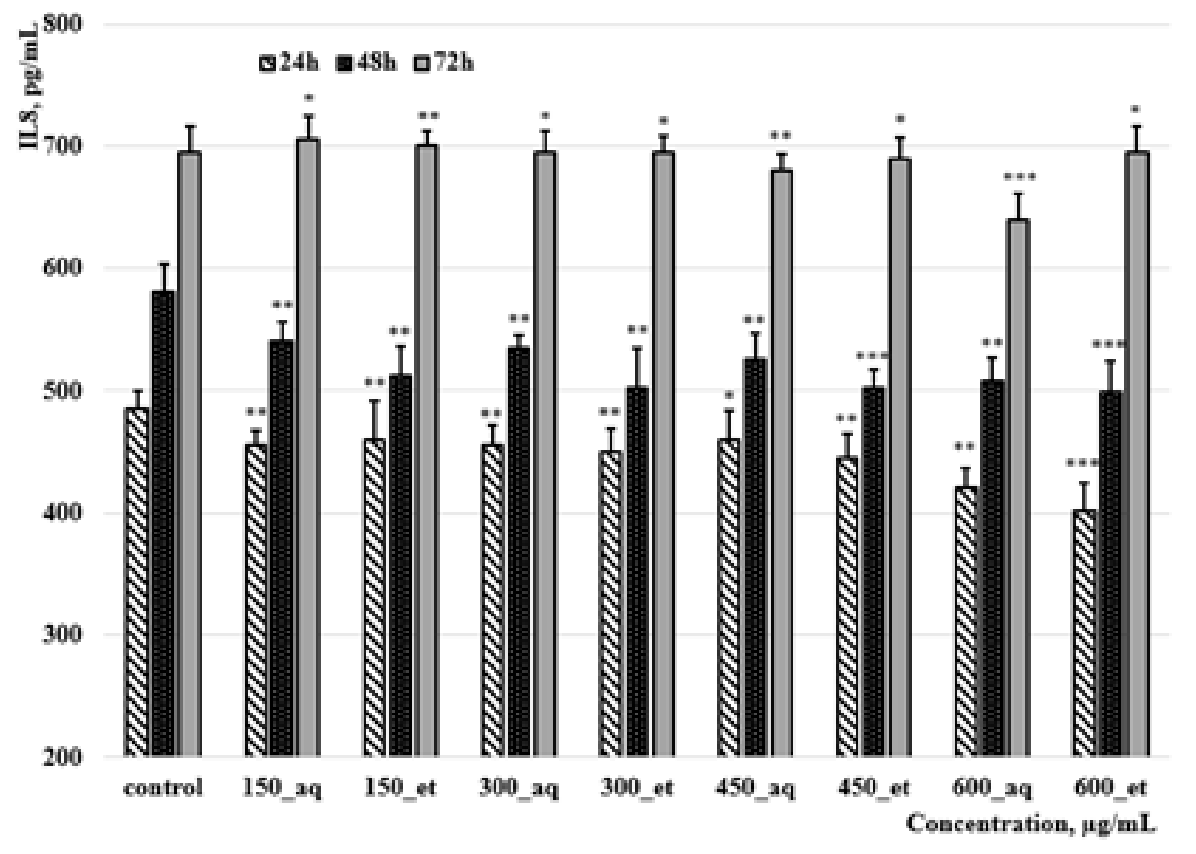

Figure 3.

Concentrations of IL8 $(\mathrm{pg} / \mathrm{mL}) ; \mathrm{aq}=$ aqueous and et $=$ ethanolic extracts $* \mathrm{p}<0.05, * * \mathrm{p}<0.01$ and $* * * \mathrm{p}<0.001 v s$. control

The effects of the biological compounds from M. pendans on angiogenesis are currently under investigation; on the other hand, it is well-known that literature [2122] describes IL- 8 as a pro-angiogenic factor that facilitates the development of angiogenesis in a few cancers. Although several studies have demonstrated their therapeutic potential in different types of cancer, the mechanisms of action on cytokines and other molecules involved in angiogenesis are not yet elucidated.

\section{Conclusions}

M. pendans, a plant from the Rubiaceae family, is often used by the Papuans as a medicinal plant that can treat tumours, gout, diarrhoea, and fever. Its extracts exert antiproliferative effects on neoplastic colonic HCT116, the cytotoxic effects being dependent on the extraction solvent properties, concentration and incubation period. In contrast, the doses studied did not significantly influence IL-8 secretion.

\section{Conflict of interest}

The authors declare no conflict of interest.

\section{References}

1. Pîrvu L, Sha'at F, Păvăloiu R, Udeanu DI, Albu B, Studies on Acinos alpinus L.: Polyphenols and terpenoids compounds profile, antimicrobial activity, antioxidant effect and release experiments on the ethanol and propylene glycol extracts. Farmacia, 2019; 67(6): 1025-1033.

2. Munteanu MF, Ardelean A, Borcan F, Trifunschi SI, Gligor R, Ardelean SA, Coricovac D, Pinzaru I, Andrica F, Borcan LC, Mistletoe and Garlic Extracts as Polyurethane Carriers - A Possible Remedy for Choroidal Melanoma. Curr Drug Deliv., 2017; 14(8): 1178-1188.

3. Borcan LC, Dudas Z, Len A, Fuzi J, Borcan F, Tomescu MC, Synthesis and characterization of a polyurethane carrier used for a prolonged transmembrane transfer of a chili pepper extract. Int J Nanomed., 2018; 13: 7155-7166. 
4. Borcan F, Chirita-Emandi A, Andreescu NI, Borcan LC, Albulescu RC, Puiu M, Tomescu MC, Synthesis and preliminary characterization of polyurethane nanoparticles with ginger extract as a possible cardiovascular protector. Int J Nanomed., 2019; 14: 3691-3703.

5. Borcan F, Preda M, Borcan LC, Pinzaru I, Florescu S, Sisu E, Poenaru M, Comparative Characterization of Birch Bark Extracts Encapsulated Inside Polyurethane Microstructures. Mater Plast., 2018; 55(3): 385-388.

6. Vlad DC, Dumitrascu V, Popescu R, Cimporescu A, Vlad CS, Flangea C, Grecu DS, Vagvolgyi C, Papp T, Horhat F, Gas Chromatography-Mass Spectrometry Evidences for New Chemical Insights of Momordica charantia. Rev Chim., 2015; 66(11): 1914-1920.

7. Anna JU, Young-Chang CHO, Ba Reum K, Sewoong L, Hien Thi Thu L, Huong Lan V, Sayeon C, Anticancer effects of methanol extract of Myrmecodia platytyrea Becc. leaves against human hepatocellular carcinoma cells via inhibition of ERK and STAT3 signaling pathways. Int J Oncol., 2018; 52(1): 201-210.

8. Gartika M, Pramesti HT, Kurnia D, Satari MH, A terpenoid isolated from sarang semut (Myrmecodia pendans) bulb and its potential for the inhibition and eradication of Streptococcus mutans biofilm. BMC Complement Altern Med., 2018; 18(1): 151: 1-8.

9. Sudiono J, Oka C, Trisfilha P, The Scientific Base of Myrmecodia pendans as Herbal Remedies. Brit J Med Med Res., 2015; 8(3): 230-237.

10. Engida AM, Kasim N, Tsigie Y, Ismadji S, Huynh $\mathrm{LH}, \mathrm{Ju} \mathrm{YH}$, Extraction, identification and quantitative HPLC analysis of flavonoids from sarang semut (Myrmecodia pendan). Ind Crops Prod., 2013; 41: 392-396.

11. Vlad CS, Dumitrascu V, Vlad DC, Popescu R, Cimporescu A, Flangea C, Cheveresan A, Sipos S, Barac B, Malita I, Effects of Materials Based on Acrylic Resines on Inflammatory Markers IL-8 and TGF $\beta 1$ in Gingival Crevicular Fluid. Mater Plast., 2018; 55(1): 111-114.

12. Du J, He Y, Li P,Wu W, Chen Y, Ruan H, IL-8 regulates the doxorubicin resistance of colorectal cancer cells via modulation of multidrug resistance 1 (MDR1). Cancer Chemother Pharmacol., 2018; 81(6): 11111119.

13. Achmad H, Supriatno, Singgih MF, Hendrastuti H, Akt signal transduction pathways and nuclear factor- kappa B (NF- $\mathrm{B})$ transcription as a molecular target of oral tongue squamous cell carcinoma (SP-C1) using Papua's anthill plant (Myrmecodia pendans). PakJ Biol Sci., 2016; 19(8-9): 323-330.

14. Achmad MH, Horax S, Ramadhany S, Rieuwpassa IE, Sari M, Hendrastuti H, Singgih MF, Sugiharto S, Anti-Cancer and Anti-Proliferation Activity of Ethyl Asetat Extract From Ant Nest (Myrmecodia pendans) in Burkitt's Lymphoma Cancer Cells. PBOCI, 2019; 19: e4325: 1-7.

15. Soeksmanto A, Subroto MA, Wijaya H, Simanjuntak $\mathrm{P}$, Anticancer activity test for extracts of Sarang semut plant (Myrmecodya pendens) to HeLa and MCM-B2 cells. Pak J Biol Sci., 2010; 13(3): 148-151.

16. Bashari MH, Hidayat S, Robles Ruswandi YA, Putri T, Qomarilla N, Dwiwina RD, Kurnia D, Satari MH, Huda F, The N-hexane fraction of Myrmecodia pendans inhibits cell survival and proliferation in colon cancer cell line. Int J Pharm Pharm Sci., 2018; 10(1): 108-112.

17. Lestari W, Yusry WNAW, Iskandar SH, Ichwan SJA, Irfan NI, Suriyah WH, Gene expression of selected apoptotic markers in human oral squamous carcinoma HSC-3 cell line treated with Myrmecodia pendans plant extract. Makara J Health Res., 2019; 23(2): 121-126.

18. Supriatno D, Antitumor activity of Papua's Myrmecodia pendans in human oral tongue squamous cell carcinoma cell line through induction of cyclin-dependent kinase inhibitor p27Kip1 and suppression of cyclin E. J Cancer Res Ther., 2014; 2(3): 48-53.

19. Sudiono J, Tri Oka C, Trisfilha P, The Scientific Base of Myrmecodia pendans as Herbal Remedies. Brit J Med Med Res., 2015; 8(3): 230-237.

20. Sudiono J, Hardina M, The effect of Myrmecodia pendans ethanol extract on inflamed pulp: study on Sprague Dawley rats. Mol Cell Biomed Sci., 2019; 3(2): 115-121.

21. Shi J, Pin-Kang W, Interleukin-8: A potent promoter of angiogenesis in gastric cancer. Oncol Lett., 2016; 11(2): 1043-1050.

22. Li A, Dubey S, Varney ML, Dave BJ, Singh RK, IL-8 directly enhanced endothelial cell survival proliferation, and matrix metalloproteinases production and regulated angiogenesis. J Immunol., 2003; 170(6): 3369-3376. 